\title{
Cancer induction molecular pathways and HF-EMF irradiation
}

\author{
Gérard Ledoigt $^{1^{*}}$, Dominique Belpomme ${ }^{2}$ \\ ${ }^{1}$ Clermont-Université, UMR PIAF Université-INRA, Blaise-Pascal University, Campus Universitaire des Cézeaux, Landais; Aubiere \\ Cedex, France \\ ${ }^{2}$ Paris-Descartes University Hospital, Medical Oncology Department, Association for Research and Treatment against Cancer \\ (ARTAC), Paris, France \\ Email: *Gerard.Ledoigt@univ-bpclermont.fr
}

Received 14 January 2013; revised 7 March 2013; accepted 10 April 2013

Copyright (C) 2013 Gérard Ledoigt, Dominique Belpomme. This is an open access article distributed under the Creative Commons Attribution License, which permits unrestricted use, distribution, and reproduction in any medium, provided the original work is properly cited.

\begin{abstract}
The response of cells to different types of electromagnetic fields can be induced by low-level (athermal) high frequency (HF) electromagnetic fields (EMFs) exposure associated with mobile phone technologies. There are many examples of biological effects involving the epigenome. EMFs could trigger protein activation mediated by ligands, such as $\mathrm{Ca}^{2+}$, that alter the conformation of binding proteins, especially the NADPH plasmic membrane oxidase, so inducing increased formation of reactive oxygen species (ROS) that may alter proteomic functions. Classical antiapoptotic and procarcinogenic signaling pathways that are commonly found activated in human malignancies and in inflammation mainly involve the transcription factor NF-KB. The microenvironment that exists during chronic inflammation can contribute to cancer progression. The data support the proposition that long term HF-EMF exposure associated with improper use of cell phones can potentially cause cancer.
\end{abstract}

Keywords: Cell Membrane; Chronic Inflammation; EMF Exposure; Gene Expression; Cancer;

Carcinogenesis; NF- $\mathrm{kB}$

\section{INTRODUCTION}

Global system for mobile communication (GSM), which being used in most of the countries, has a frequency of either 900 or $1800 \mathrm{MHz}$. This low-energy (non-thermal) radiation is emitted not only by cell phones themselves, but also by the base stations. There are many examples

*Corresponding author. of biological effects resulting from low-level (athermal) EMF exposure [1-4].

The environment is a well-established source of damaging or disrupting influences on cellular function. In the past, studies of the mechanisms by which such disruptions occur have focused largely on either direct toxic effects on cellular function at the protein or cell signaling level, or mutagenic effects that impact the genome [4]. In recent years there has been a growing appreciation for the potential for environmental influences to disrupt the epigenome and mechanisms of epigenetic regulation within the cell. Indeed, because of the inherent lability of the epigenome, this represents a primary target for environmentally induced disruption [5].

Chronic inflammation has long been associated with the development of cancer [6-8]. Although inflammation is part of the defense response, paradoxically it can lead to important health disorders. Since it was discovered in the 19th century, chronic inflammation has been proven to be involved both at the initiation/promotion and progression phases of carcinogenesis [9]. This is mainly due to the fact that inflammatory response is followed by a proliferative cellular effect in tissus (basal cell hyperplasia, papillary elongation) [10].

An office workers cohort with high EMF exposure showed a cancer increase, with a high risk of malignant melanoma. School teachers exposed to a type of Radio-frequency radiation (RFR) had increased incidence of malignant melanoma and thyroid cancer [11]. Pooling of data from Nordic countries and part of the UK yielded a significantly increased risk of glioma and a significantly increased risk of acoustic neurinoma related to use of mobile phones for a period of 10 years or more on the side of the head where the tumour developed $[12,13]$. In an Israeli study, where study subjects tended to report 
substantially heavier use of mobile phones, results suggest a possible relation between heavy mobile phone use and risk of parotid gland tumours [14]. Several reports have indicated that EMFs enhance free radical activity in cells particularly via the Fenton reaction $[15,16]$.

\section{CELL RESPONSES}

Duckweed growth and peroxidase activity was evaluated after exposure in a Gigahertz Transversal Electromagnetic (GTEM) cell to electromagnetic fields of frequencies 400, 900, and $1900 \mathrm{MHz}$. Growth of plants exposed for $2 \mathrm{~h}$ to $23 \mathrm{~V} / \mathrm{m}$ electric field of $900 \mathrm{MHz}$ significantly decreased in comparison with the control, while an electric field of the same strength but at $400 \mathrm{MHz}$ did not have such effect. At both frequencies a longer exposure mostly decreased the growth and the highest electric field $(390 \mathrm{~V} / \mathrm{m})$ strongly inhibited the growth. Exposure of plants to lower field strength $(10 \mathrm{~V} / \mathrm{m})$ for $14 \mathrm{~h}$ caused significant decrease at 400 and $1900 \mathrm{MHz}$ while 900 $\mathrm{MHz}$ did not influence the growth. Peroxidase activity in exposed plants varied, depending on the exposure characteristics. Observed changes were mostly small, except in plants exposed for $2 \mathrm{~h}$ to $41 \mathrm{~V} / \mathrm{m}$ at $900 \mathrm{MHz}$ where a significant increase $(41 \%)$ was found. Therefore, the effects of EMFs strongly depended on the characteristics of the field exposure [17].

Exposure of tomato plants to non-thermal high frequency electromagnetic field (HF-EMF, $900 \mathrm{MHz}, 5$ $\mathrm{V} \cdot \mathrm{m}^{-1}$ ) for $10 \mathrm{~min}$ led to show a direct relationship between HF-EMF exposure and responses at the level of gene expression [1]. There was no direct link between the amplitude of the stimulation and the amplitude of the plant response, which suggested the concept of an "all-or-nothing" response with a threshold of induction [18]. The energy used in the electromagnetic exposure (900 MHz, $5 \mathrm{~V} \cdot \mathrm{m}^{-1}, 10 \mathrm{~min}$ ) was very low (close to 0.1 $\mathrm{W}$ dissipated in $200 \mathrm{~m}^{3}$ ) and did not produce any thermal effect $[1,18]$. The genesis and/or transmission of the informative signal were rapid and strongly dependent upon calcium. Expression of Hsp70 [19], and tumor suppressor p53 [20] are also affected by microwave irradiation.

Electromagnetic irradiation emitted from mobile phones (frequency $900 \mathrm{MHz}$ ) induces expression of proteins in various cells [21-23]. The specific absorption rate (SAR) level to which cells were exposed was 2.8 $\mathrm{W} / \mathrm{kg}$. The effects observed were not caused by bulk heating of the cells [22]. Among the proteins whose expression is induced by mobile phone irradiation are transcription factors [21]. The proteomes of the same cell type (endothelium) but derived from different vascular beds (umbilical vein and brain microvasculature) differ widely in their expression. The effect is frequency-dependent. When cells were exposed for $1 \mathrm{~h}$ at an average
SAR of $2.0 \mathrm{~W} / \mathrm{kg}$ and examined immediately thereafter, $1800 \mathrm{MHz}$ GSM radiation exposure had only very limited effect on the proteome of human endothelial cell line EA.hy926, as compared with the effect of $900 \mathrm{MHz}$ GSM radiation [24]. Mobile phone radiation might alter protein expression in human skin, with a SAR of 1.3 $\mathrm{W} / \mathrm{kg}$ induced in the skin, below the ICNIRP (International Commission on Non-Ionizing Radiation Protection) safety guidelines $(2.0 \mathrm{~W} / \mathrm{kg})$, for one hour [25].

Paulraj and Behari [26] indicated DNA single strand break and decrease in level of protein kinase at $2.45 \mathrm{GHz}$ [27]. More recently, Kesari and Behari [28] reported that microwave $(2.45 \mathrm{GHz})$ exposure cause infertility by decreasing sperm count and an increase in apoptosis.

Tkalec et al. [29] showed that non-thermal exposure to the radiofrequency fields can induce mitotic aberrations in root meristematic cells of A. сера. The observed effects were markedly dependent on the field frequencies (400 and $900 \mathrm{MHz}$ ) applied as well as on field strength and modulation. They also indicate that mitotic effects of RF-EMF could be due to impairment of the mitotic spindle.

Microwave (MW) exposure at the water resonance frequency, i.e. exposure to radiofrequencies between about $1 \mathrm{GHz}$ and $300 \mathrm{GHz}$, was able to induce alteration of the mitotic apparatus and apoptosis as a function of the applied power densities $\left(5\right.$ and $\left.10 \mathrm{~mW} / \mathrm{cm}^{2}\right)$, together with a moderate reduction in the rate of cell division. After an exposure time of $15 \mathrm{~min}$ the proportion of aberrant spindles and of apoptotic cells was significantly increased, while the mitotic index decreased as well, as compared to the untreated V79 cells. Ballardin et al. [30] hypothesised that short-time MW exposures at the water resonance frequency cause, in V79 cells, reversible alterations of the mitotic spindle, this representing, in turn, a pro-apoptotic signal for the cell line.

Another mechanism that could be involved in the formation of aberrant spindles concerns the polar protein structures. Microtubule fibers represent extremely dynamic structure which functioning depends on dynamical instability that is continuously binding and releasing of free tubule proteins. One can reasonably assume that the external EM radiation might interact with polar cytoskeletal structure. This structure greatly contributes to the balance between internal physiological electrostatic forces. Depending on the dipole moment, an external electric field could theoretically disturb the equilibrium [31] and increase the number of free cytoplasmatic tubulin proteins following a mechanism of depolarization of tubulins involved in the formation of the mitotic apparatus. Recently, it has been shown that electromagnetic field $(90 \mathrm{~V} / \mathrm{m}$ at $835 \mathrm{MHz})$ exposure can induce significant increases of mitotic disturbances in human-hamster hybrid cells [32]. 


\section{EMF-TARGET MOLECULE INTERACTIONS}

Energy transfer of Microwaves (MW) is conducted through two mechanisms, dipole rotation and ionic conduction [33]. Blank and Soo [34] examined the EMF effects on electron transfer and concluded that EMF accelerate all linked redox reactions. Blank [35] considered examples of direct effects of electric and magnetic fields on charge transfer in biological systems, and reported the structural changes driven by such effects. He concluded that conformational changes arising from alterations in charge distribution play a key role in membrane transport proteins, including ion channels. Thus, weak EMFs can control and amplify biological processes through their effects on charge distribution [3].

EMFs could interact with moving charges or charged species [36] which are implicated in various biological processes. Moreover, HF-EMF may lead to ion movement, directly or indirectly, and particularly near the plasma membrane [37] and this could initiate the biological response. Ligands, such as $\mathrm{Ca}^{2+}$, alter the conformation of proteins and hence control their receptor function. EMF exposure produces changes in binding probability of the ligand. Occupation of one protein site by a ligand changes its conformation. This suggests that EMF could trigger a transition from a random array to an ordered array of phase transition in proteins [38]. Calcium has been well recognised as a signaling factor involved in the regulation of a wide range of cellular processes involving cell proliferation.

Panagopoulos et al. [39] have suggested that oscillating ions during forced vibration will also exert mechanical force-pressure on the plasma membrane able to upset the membrane electrochemical balance, under certain conditions, by opening or closing mechanically gated channel proteins, like some $\mathrm{Ca}$ influx channels. The irregular gating of ion channels caused by the forced vibration of the free ions, induced by external oscillating EMFs, is a fact that could upset the electrochemical balance of the plasma membrane and, consequently, the whole cell function.

\section{TRANSDUCTION SIGNALS AND ONCOGENE EXPRESSION}

Currently, cancer is recognized as a disease associated with both genetic and epigenetic alterations, and both of these components cooperate and complement each other to initiate and promote cancer development and progression [40]. The carcinogenic process can be associated to a modification of gene expression regulation; the modification of the signal cascade into the cell can induce the dysregulation of transcription factor activities (overexpression, activation, uninhibition...) through the activa- tion of specific cellular messengers. Free radicals play an essential role in the activation of certain signaling pathways [6]. The effects of reactive oxygen species (ROS) on cell proliferation occurred exclusively at low or transient concentrations of radicals that can stimulate proliferation and enhanced survival in a wide variety of cell types [41]. ROS can play a very important physiological role as secondary messengers. This includes regulation of the cytosolic calcium concentration, which itself regulates biological activities, regulation of protein phosphorylation and activation of certain transcription factors such as Nuclear Factor NF- $\kappa$ B and the AP-1 family factors [41-43].

In general, the balance between the production and scavenging of ROS leads to homeostasis. Disturbance of this equilibrium can alter normal cellular processes; it often occurs in tumour cells [44]. The cumulative production of ROS through either endogenous or exogenous insults is termed oxidative stress and is common for many types of cancer with altered redox regulation of cellular signaling pathways [45]. A sustained oxidative stress has been associated with several steps of carcinogenesis, including malignant transformation and achievement of a metastatic phenotype [46]. Thornber et al. [47] have shown that, in large cell lymphoma the nucleophosmin-anaplastic lymphoma kinase (NPM-ALK) induces the production of reactive oxygen species (ROS) by a pathway involving the arachidonic acid-metabolizing enzymes of the lipoxygenase (LOX) family. The NPM-ALK chimeric gene encodes a constitutively activated tyrosine kinase that has been shown to be a potent oncogene.

Several MAPkinases, signal transducers and activators of transcription, Akt/protein kinase B and phospholipase D-signaling pathways are all activated by ROS $[48,49]$ but in some cases, activation is indirect [50].

Cadmium $(\mathrm{Cd})$ is a toxic metal causing nephrotoxicity, immunotoxicity, osteotoxicity and tumors after prolonged exposure. Cd-generated ROS are often accompagnied by activation of redox sensitive transcription factors, such as NF- $\mathrm{B}$, and alteration of ROS-related gene expression. Acquired $\mathrm{Cd}$ tolerance with aberrant gene expression plays important roles in chronic $\mathrm{Cd}$ toxicity and carcinogenesis [51]. Chronic inflammation induced by biological, chemical and physical agents, is associated with increased risk of tumors development in various organs and tissues. Association of cancer with chronic inflammation has been described, in particular, in pathological processes in organs of the digestive system, where the risk of carcinogenesis increases as much as chronic inflammation occurs (esophagitis, gastritis, hepatitis etc.). Mediators of inflammation, which contribute to the process of malignant transformation, affect many aspects of cancer cell behavior, including pro- 
liferation, differentiation and apoptosis. Inflammation contributes to initiation and promotion, i.e. to malignant transformation of normal cells and to tumor progression due to production of both proinflammatory cytokines and various forms of reactive oxygen and nitrogen species. Significant activation of NF- $\mathrm{KB}$ can stimulate malignant transformation and progression, providing antiapoptotic and proliferative signals.

Developmental signaling pathways that regulate normal stem cell self-renewal have been shown to be active in numerous human cancers [52]. Inflammatory breast cancer (IBC) is an uncommon disease accounting for $1 \%$ $5 \%$ of all breast cancers [53,54]. Experimental evidence now solidly validates the HER2 oncogene hypothesis and etiologically links amplification of the HER2 gene locus with human cancer pathogenesis [55]. HER2 protein overproduction is not only seen in breast cancer but also uncommonly in cancers of the esophagus, stomach, ovaries and endometrium. Mutations in the HER2 gene are found rarely in these cancers but overexpression appears to be the principal mechanism by which HER 2 mediates tumorigenesis in these cancers [56].

\section{SIGNAL TRANSDUCTION AND EMF SIGNALING PATHWAYS}

Mitogen-activated-phospho-kinase (MAPK) family pathway control cell proliferation, metabolism and cell survival in response to tissue injury, infection, malignancy and other diseases. Activation of the MAPK cascades leads to phosphorylation of transcription factors that bind to the upstream regulatory elements on the gene promoter, relative to the transcription initiation site. Three out of four MAPK cascades are differentially activated by Extremely Low Frequency (ELF-EMF) [57].

The signaling pathways and stress responses are activated by EMF. Friedman et al. [58] have shown that the initial step in transmitting extracellular EMF information from the plasma membrane to the nucleus of the cell occurs when NADH oxidase rapidly generates ROS. These ROS stimulate matrix metalloproteinases, and then activate the extracellular signal regulated kinase (ERK$1 / 2$ ) cascade. These changes in activity of the protein kinases pathways can consequently regulate the physiological response of the exposed cells and organisms, and therefore are major regulators of the effects of electromagnetic fields at mobile phone frequencies.

Data indicate that, prior to the stress responses, mobile phone irradiation induces an immediate intracytoplasmic effect which activates ERK signalling to induce further transcription of a variety of genes [59]. The fact that the stress-related cascades, which are known to be activated by heat or other related stressors, were not activated, in the time course of Friedman et al. [58] experiments, in- dicates that the activation of ERKs is induced by other mechanisms. It has been reported that within $10 \mathrm{~min}$ of cell phone exposure, two MAPKinase cascades, p38 and ERK1/2, are activated [60].

Both ELF and RF radiations can upregulate the HSP70 gene and induce elevated levels of the Hsp70 protein. This effect on RNA transcription and protein stability is controlled by specific protein transcription factors that are elements of the mitogen MAPK cascade. EMF can also stimulate serum response factor which binds to the serum response element (SRE) through ERK MAPK activation and is associated with injury and repair in vivo and in vitro. The SRE site is on the promoter of an early response gene, c-fos, which under specific cellular circumstances has oncogenic properties. The c-fos promoter is EMF-sensitive [61,62].

Activation of NF- $\kappa$ B and AP-1, the downstream of the MAPK or PI3K-Akt signaling pathways, are involved in many pathological processes, such as inflamemation, cancer cell adhesion, invasion, migration, and angiogenesis $[63,64]$. NF- $\mathrm{kB}$ and AP-1 transcription factors function as crucial regulators of inflammatory and immune responses as well as of cell survival. They have been implicated in cellular transformation and tumorigenesis. The NF- $\mathrm{KB}$ pathway is required for the development of tumours in a mouse model of lung adenocarcinoma [65]. Elevated P13K/PDK/Akt or NF-kB signaling (or both) have been correlated with advanced tumor progression and poor prognosis in patients with breast cancer $[66,67]$.

$\mathrm{NF}-\mathrm{kB}$ is maintained in the cytoplasm through interac-

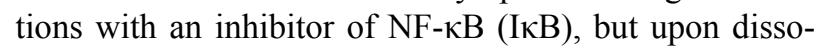
ciation, it moves into the nucleus and promotes cancer cells proliferation, angiogenesis, and metastasis. Carcinogens and tumour promoters involving toxic metals, UV radiation, phobol esters, asbestos, alcohol and benzo $(\alpha)$ pyrene are among the external stimuli that activate NF- $\mathrm{KB}$ [68]. Hepatitis B viral proteins (HBx) have oncogenic properties by activation of different promoter elements and then trigger activation of transcription factors such as AP-1 and NF- $\mathrm{kB}[45,69]$.

In fact NF- $\kappa B$ is a transcriptional factor that regulates a battery of genes that are critical to innate and adaptive immunity, cell proliferation, inflammation, and tumor development [70]. Increasing evidence suggests that the physiological NF- $\mathrm{kB}$-associated pathways are dysregulated in numerous malignancies [66,71-74]. The activation of NF-kB-dependent anti-apoptotic genes may promote IBC tumorigenesis and, other inflammation-associated tumor types [75]. The NF- $\mathrm{BB}$ pathway appears to play a major role in IBC, possibly contributing to the unusual phenotype and aggressiveness of this form of breast cancer [76]. DNA microarrays studies of IBC have shown abnormal expression of several NF- $\kappa B$ 
target genes $[77,78]$. Activated NF- $\mathrm{KB}$ translocates to the nucleus and binds to the DNA to initiate expression of genes that enhances cell proliferation and survival $[67$, 73,79].

Indeed, activation of the transcription factor $\mathrm{NF}-\kappa \mathrm{B}$, one of the most investigated nuclear transcription factors, has been found to control multiple cellular processes in cancer including inflammation, transformation, proliferation, angiogenesis, invasion, metastasis, chemoresistance and radioresistance. $\mathrm{NF}-\kappa \mathrm{B}$ is constitutively active in most cancer cells, and its suppression inhibits the growth of tumor cells, leading to the concept of "NF- $\kappa \mathrm{B}$ addiction" in cancer cells. As NF- $\kappa \mathrm{B}$ is the key transcription factor involved in inflammation, and inflammation is frequently associated with cancers, many of the signaling pathways implicated in cancer are likely to be networked to the activation of NF- $\kappa$ B. NF- $\kappa B$ interacts with many transcription factors and transcriptional regulators [80].

Chronic inflammation has been associated with the development of cancer. Molecular biology studies have shown that there are genes, which when "activated" (oncogenes) or "inactivated" (tumour suppressor genes) contribute to the clonal expansion of an initiated stem cell. Cancer would thus be a disease of homeostasis [45]. Any exposure, including prolonged low-intensity ELF and RF exposures that result in increased free radical production may be considered a plausible biological mechanism for carcinogenesis [6].

\section{CONCLUSIONS: HYPOTHETIC MODELISATION}

Oncogenesis is suggested to be mediated by a sustained and not a transient ERK activation [58] that could be an explanation for the possible increased cancer risk that may be associated with base station antenna. RF field studies have shown that RFF exposure is followed by the stimulation of cell proliferation and activation of stress proteins [57]. In the present overview, production of ROS by mobile phone irradiation, a process that has already been evidenced in previous studies [81,82], is suggested to be induced by the activation of NADH oxidase, which appears to be an early target of mobile phone irradiation. These events appear to occur within seconds and could initiate subsequent activation of pathways that lead to phosphorylation of ERKs. Several components of the proposed model (Figure 1) have been implicated in activation of the ERK cascade in different cellular systems.

Microwave effects have been always mainly observed in stem cells. This result suggests both significant misbalance in double strand break (DSB) repair and severe

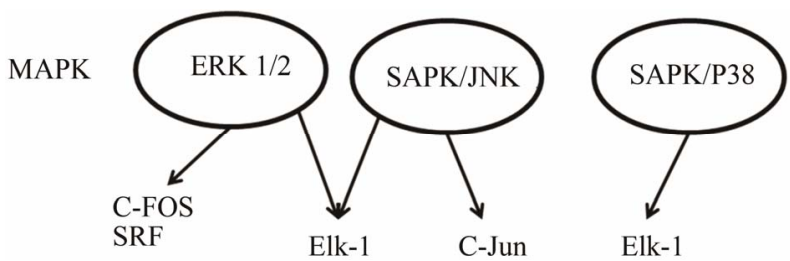

Figure 1. The mitogen activated protein kinase (MAPK) signaling cascades identified to date are: extracellular signal regulated kinase 1/2 (ERK), c-Junterminal kinase (JNK), p38-MAPK and stress activated protein kinase (SAPK). Elements of the three MAPkinase pathways that have been identified as activated by EMF are shown in the shaded circles, according to Weisbrot et al. [57].

stress responses. Findings that stem cells are most sensitive to microwave exposure and react more strongly to EMF than do differentiated cells may be important for cancer risk assessment and indicate that stem cells are the most relevant model for studying mobile-induced intracellular communication signals [83].

Brain cell cultures of mice were exposed to 10.715 $\mathrm{GHz}$ with specific absorbtion rate (SAR) of $0.725 \mathrm{~W} / \mathrm{kg}$ signals for $6 \mathrm{~h}$ in 3 days at $25^{\circ} \mathrm{C}$ to assess the changes in the micronucleus (MNi) assay and in the expression of 11 proapoptotic and antiapoptotic genes. It was found that MNi rate increased 11-fold and STAT3 expression decreased 7-fold in the cell cultures exposed to RF. Cell phones which spread RF may damage DNA and change gene expression in brain cells. The data support the proposition that cell phones may have a potential to cause hazardous effects on the genome; however, in in vivo conditions, the duration of exposure and the capacity of DNA repair may prevent the development of cancer [84].

An interesting question raised in studies is what could be the early molecular target of mobile phone irradiation. Results of Friedman et al. [58] indicated that the early target could be NADH oxidase, which is localized in the plasma membrane and converts EMF irradiation into ROS.

However, the earliest target receptor of HF-EMF could be calcium ions stored on the external surface of cell membrane. The proposed HF-EMF induction pathway is resumed in Figures $\mathbf{2}$ and 3. Near the plasma membrane, EMFs could induce $\mathrm{Ca}^{++}$ion movement, directly or indirectly, and activate $\mathrm{NAD}(\mathrm{P}) \mathrm{H}$ oxydase, a calcium-dependent enzyme. Its activity leads to the production of superoxide ion and hydrogene peroxide. Alternatively, the production of ROS would also activate several calcium channels, then enhancing the calcium ion concentration that is required for signal transduction. ROS can function as cellular second messengers that are likely to modulate the action of many different proteins, so leading to a variety of responses. The nuclear trans- 


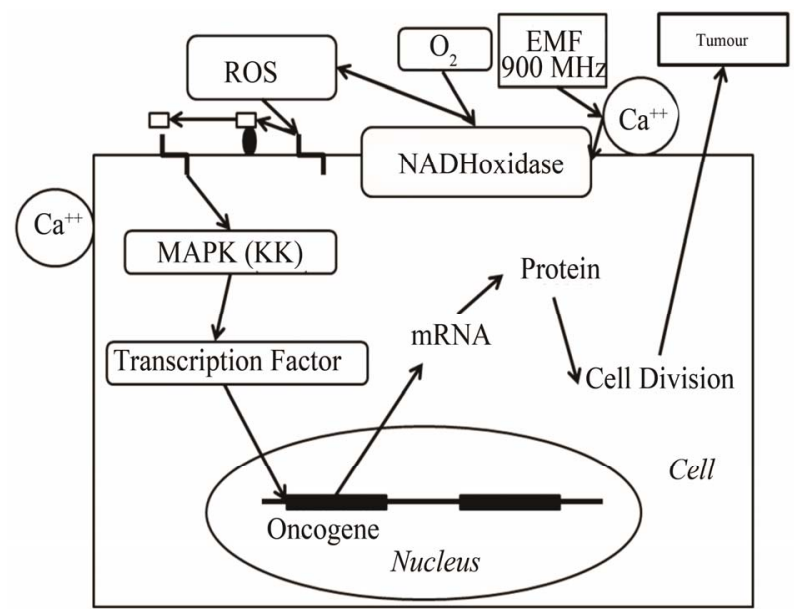

Figure 2. Cell survival after EMF stimuli. Schematic representation of proposed mechanism that mediates the phosphorylation of transcription factors upon mobile phone irradiation. EMFs $(900 \mathrm{MHz})$ could shift calcium ions that trigger changes in the nearby enzyme NAD(P)H oxidase. The enzyme generates ROS that can induce membrane proteins involved in formation of the signal message. Signal transduction could activate calciproteins, then MAP kinases and transcription factors that would activate oncogene expression. In turn, EMFs $(900$ $\mathrm{MHz}$ ) could activate calcium channels that would allow the induction of the cell transduction signal cascade.

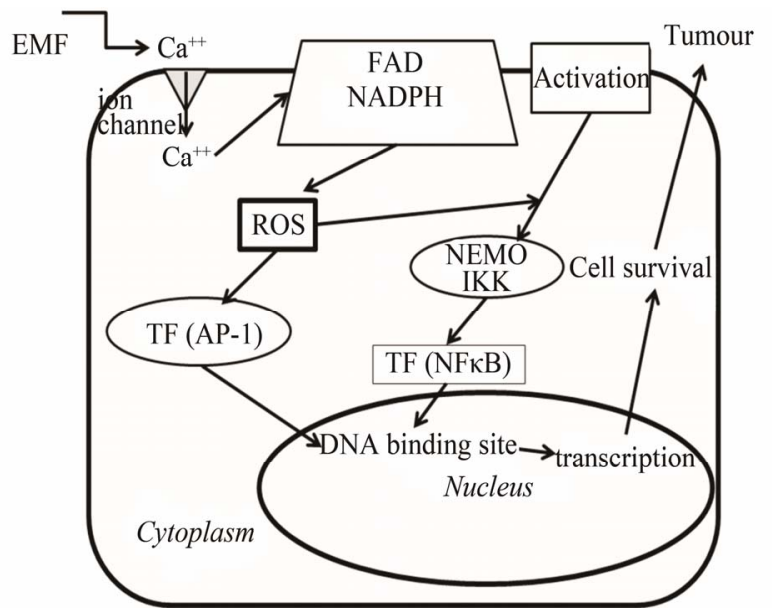

Figure 3. Cell transduction signal after EMF stimuli. Following targeting various agents (activation) on cell membrane, IкB proteins are phosphorylated by a protein kinase complex (IKK) and a regulation element (NEMO), then I $\mathrm{KB}$ is ubiquitinated. Proteasomal degradation is proceeded allowing the translocation of the NF- $\mathrm{KB}$ complexes in the nucleus where they bind to the gene promoters which are invoved in cell response [91]. EMF can activate a cell membrane calcium channel which allows triggering of membrane NADPH oxidase. The latter enzyme is part of a mechanism producing reactive oxygen species (ROS) that can activate transcription factors (TF) such as AP-1 and/or NF- $\kappa$ B. Oxidizing stimuli in the cytosol lead to post-translational transcription factor modification that facilitates translocation to the nucleus. The transcription factor can bind to the DNA site of oncogene promoters that trigger cell survival and tumour development.

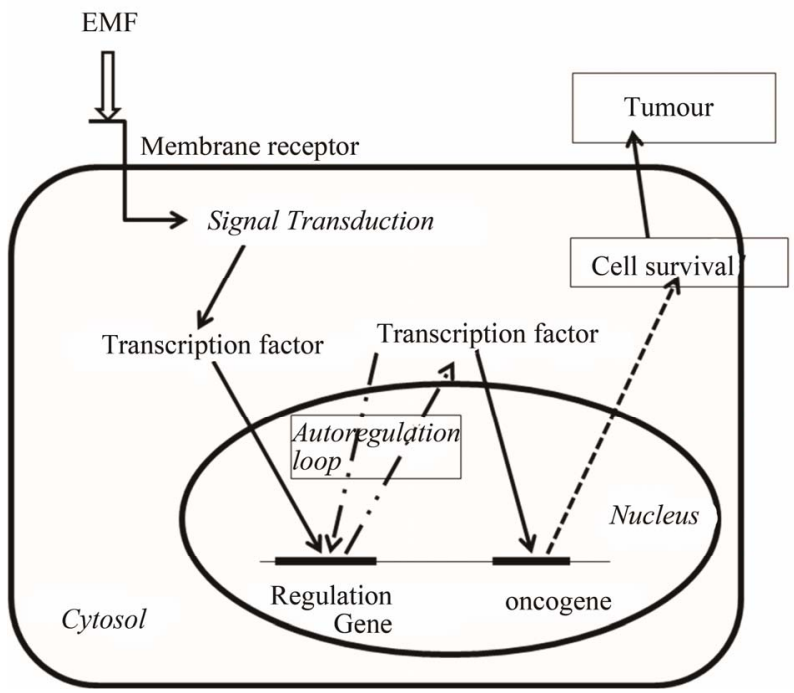

Figure 4. Cell survival homeostasis after EMF stimuli. EMF could trigger cell signal transduction through membrane receptor. Activated transcription factors would allow the expression of genes involved in cell survival together with transcription factor genes resulting in permanent cell survival and tumour development.

cription factor, NF- $\mathrm{kB}$, is maintained in the cytoplasm through interactions with its inhibitor I $\kappa \mathrm{B}$, but upon dissociation, as previously indicated, it moves into the nucleus and promotes cancer cell proliferation, angiogenesis, and metastasis (Figure 2). In addition, EMF could activate ion movements thus allowing the activation of calcium channels, activating $\mathrm{NAD}(\mathrm{P}) \mathrm{H}$ oxidase and inducing signal transduction for oncogene expression (Figure 3). Consequently a modelling of cell survival homeostasis following EMF stimuli can be proposed (Figure 4). The EMF stimuli might trigger the expression of transcription factors that could develop some type of permanent loop of gene expression. Transcription factors could thus induce the permanent expression of oncogenes involved in survival and proliferation of cancer cells (Figure 4).

The microenvironment that is associated with chronic inflammation can contribute to cancer progression $[7,85]$. Macrophages are key mediators of the interaction between inflammation, immunity and cancer. The role of macrophages in cancer has recently received special attention due to the discovery of their tumor-promoting effects [86-88]. Inhibition in macrophages activity during tumorigenesis at certain check points may interfere with host-suppressive effects on metastasis formation, and suggests that timing and cell specificity may be key determinants of the impact of specific NF- $\mathrm{kB}$ inhibitors used as cancer therapy [89]. Tumor growth increases inflammation and recent data have indicated that in cancer, high oxidative stress can be detected [7].

Panagopoulos and Margaritis [90] showed that GSM 
$900 \mathrm{MHz}$ radiation is slightly more bioactive than Digital Cellular System (DCS) $1800 \mathrm{MHz}$ radiation, at the same exposure durations and under equivalent radiation intensities. Exposure to mobile telephony radiation may have adverse health effects and thus mobile telephony use should be restricted within more rigorous defined limits of exposure. Since radiation intensity in their experiments was 45 and 90 times lower than the current exposure limits for 900 and $1800 \mathrm{MHz}$, respectively, this suggests the need for a significant reduction of the current exposure limits.

\section{ACKNOWLEDGEMENTS}

The authors wish to acknowledge the help of Pr. Ernesto Burgio (ISDE) and Dr. P. Irigaray (ARTAC).

\section{REFERENCES}

[1] Roux, D., Vian, A., Girard, S., Bonnet, P., Paladian, F., Davies, E. and Ledoigt, G. (2006) Electromagnetic fields (900 MHz) evoke consistent molecular responses in tomato plants. Physiologia Plantarum, 128, 283-288. doi:10.1111/j.1399-3054.2006.00740.x

[2] Hardell, L., Carlberg, M., Soderqvist, F., Mild, K.H. and Morgan, L.L. (2007) Longterm use of cellular phones and brain tumors: Increased risk associated with use for $\geq 10$ years. Occupational and Environmental Medicine, 64, 626-632. doi:10.1136/oem.2006.029751

[3] Mousavy, S.J., Riazi, G.H., Kamarei, M., Aliakbarian, H., Sattarahmady, N., Sharifizadeh, A., Safarian, S., Ahmad, F. and Moosavi-Movahedi, A.A. (2009) Effects of mobile phone radiofrequency on the structure and function of the normal Human Hemoglobin. International Journal of Biological Macromolecules, 44, 278-285. doi:10.1016/j.ijbiomac.2009.01.001

[4] Belpomme, D., Irigaray, P., Hardell, L., Clapp, R., Montagnier, L., Epstein, S. and Sasco, A.J. (2007) The multitude and diversity of environmental carcinogens. Environmental Research, 105, 414-429. doi:10.1016/j.envres.2007.07.002

[5] McCarrey, J.R. (2012) The epigenome as a target for heritable environmental disruptions of cellular function. Molecular and Cellular Endocrinology, 354, 9-15. doi:10.1016/j.mce.2011.09.014

[6] Hardell, L. and Sage, C. (2008) Biological effects from electromagnetic field exposure and public exposure standards. Biomedicine \& Pharmacotherapy, 62, 104-109. doi:10.1016/j.biopha.2007.12.004

[7] Mantovani, A., Allavena, P., Sica, A. and Balkwill, F. (2008) Cancer-related inflammation. Nature, 454, 436444. doi: $10.1038 /$ nature 07205

[8] Bollrath, J. and Greten, F.R. (2009) IKK/NF and STAT3 pathways: Central signalling hubs in inflammation-mediated tumour promotion and metastasis. EMBO Report, 10, 1314-1319. doi:10.1038/embor.2009.243

[9] Hernandez, M., Martın, R., Garcıa-Cubillas, M.D., Mae-
so-Hernandez, P. and Nieto, M.L. (2010) Secreted PLA induces proliferation in astrocytoma through the EGF receptor: Another inflammation-cancer link. Neuro-Oncology, 12, 1014-1023. doi:10.1093/neuonc/noq078

[10] Kandulski, A. and Malfertheiner, P. (2012) Gastroesophageal reflux disease-From reflux episodes to mucosal inflammation. Nature Reviews Gastroenterology \& Hepatology, 9, 15-22.

[11] Milham, S. (2009) Most cancer in firefighters is due to radio-frequency radiation exposure not inhaled carcinogens. Medical Hypotheses, 73, 788-789. doi:10.1016/j.mehy.2009.04.020

[12] Schoemaker, M.J., Swerdlow, A.J., Ahlbom, A., Auvinen, A., Blaasaas, K.G., Cardis, E., Christensen, H.C., Hepworth, S.J., Feychting, M., Johansen, C., Klaeboe, L., Lönn, S., McKinney, P.A., Muir, K., Raitanen, J., Salminen, T., Thomsen, J. and Tynes, T. (2005) Mobile phone use and risk of acoustic neuroma: Results of the Interphone case-control study in five North European countries. British Journal of Cancer, 93, 842-848. doi:10.1038/sj.bjc. 6602764

[13] Lahkola, A., Salminen, T. and Auvinen, A. (2005) Selection bias due to differential participation in a case-control study of mobile phone use and brain tumors. Annals of Epidemiology, 15, 321-325.

doi:10.1016/j.annepidem.2004.12.009

[14] Sadetzki, S., Chetrit, A., Jarus-Hakak, A., Cardis, E., Deutch, Y., Duvdevani, S., Zultan, A., Novikov, I., Freedman, L. and Wolf, M. (2008) Cellphone use and risk of benign and malignant parotid gland tumors-A nationwide case-control study. American Journal of Epidemiology, 167, 457-467. doi:10.1093/aje/kwm325

[15] Belpomme, D., Irigaray, P. and Hardell, L. (2008) Electromagnetic fields as cancer-causing agents. Environmental Research, 107, 289-290. doi:10.1016/j.envres.2008.01.017

[16] Lai, H. and Singh, N.P. (2004) Magnetic-field-induced DNA strand break in brain cells of the rat. Environmental Health Perspectives, 112, 687-694. doi:10.1289/ehp.6355

[17] Tkalec, M., Malarić, K. and Pevalek-Kozlina, B. (2005) Influence of 400,900 , and $1900 \mathrm{MHz}$ electromagnetic fields on Lemna minor growth and peroxidase activity. Bioelectromagnetics, 26, 185-193. doi:10.1002/bem.20104

[18] Roux, D., Vian, A., Girard, S., Bonnet, P., Paladian, F., Davies, E. and Ledoigt G. (2008) High frequency (900 $\mathrm{MHz})$ low amplitude $\left(5 \mathrm{~V} \cdot \mathrm{m}^{-1}\right)$ electromagnetic field: A genuine environmental stimulus that affects transcription, translation, calcium and energy charge in tomato. Planta, 227, 883-891. doi:10.1007/s00425-007-0664-2

[19] Lantow, M., Lupke, M., Frahm, J., Mattsson, M.O., Kuster, N. and Simko, M. (2006) ROS release and Hsp70 expression after exposure to $1800 \mathrm{MHz}$ radiofrequency electromagnetic fields in primary human monocytes and lymphocytes. Radiation and Environmental Biophysics, 45, 55-62. doi:10.1007/s00411-006-0038-3

[20] Czyz, J., Guan, K., Zeng, Q., Nikolova, T., Meister, A., Schönborn, F., Schuderer, J., Kuster, N. and Wobus, A.M. (2004) High frequency electromagnetic fields (GSM sig- 
nals) affect gene expression levels in tumor suppressor p53-deficient embryonic stem cells. Bioelectromagnetics, 25, 296-307. doi:10.1002/bem.10199

[21] Chauhan, V., Mariampillai, A., Bellier, P.V., Qutob, S.S., Gajda, G.B., Lemay, E., Thansandote, A. and McNamee, J.P. (2006) Gene expression analysis of a human lymphoblastoma cell line exposed in vitro to an intermittent $1.9 \mathrm{GHz}$ pulse-modulated radiofrequency field. Radiation Research, 165, 424-429. doi:10.1667/RR3531.1

[22] Nylund, R. and Leszczynski, D. (2006) Mobile phone radiation causes changes in gene and protein expression in human endothelial cell lines and the response seems to be genome- and proteome-dependent. Proteomics, 6, 47694780. doi: $10.1002 /$ pmic. 200600076

[23] Remondini, D., Nylund, R., Reivinen, J., Poulletier de Gannes, F., Veyret, B., Lagroye, I., Haro, E., Trillo, M.A., Capri, M., Franceschi, C., Schlatterer, K., Gminski, R., Fitzner, R., Tauber, R., Schuderer, J., Kuster, N., Leszczynski, D., Bersani, F. and Maercker, C. (2006) Gene expression changes in human cells after exposure to mobile phone microwaves. Proteomics, 6, 4745-4754. doi:10.1002/pmic.200500896

[24] Nylund, R., Kuster, N. and Leszczynski, D. (2010) Analysis of proteome response to the mobile phone radiation in two types of human primary endothelial cells. Proteome Science, 18, 8-52.

[25] Karinen, A., Heinävaara, S., Nylund, R. and Leszczynski, D. (2008) Mobile phone radiation might alter protein expression in humanb skin. BMC Genomics, 9, 77 doi:10.1186/1471-2164-9-77

[26] Paulraj, R. and Behari, J. (2006) Single strand DNA breaks in rat brain cells exposed to microwave radiation. Mutation Research, 596, 76-80. doi:10.1016/i.mrfmmm.2005.12.006

[27] Paulraj, R. and Behari, J. (2004) Radiofrequency radiation effect on protein kinase $\mathrm{C}$ activity in rats brain. $\mathrm{Mu}$ tation Research, 585, 127-131. doi:10.1016/S0027-5107(03)00113-1

[28] Kesari, K. K., and Behari, J. (2010) Effect of microwave at $2.45 \mathrm{GHz}$ radiations on reproductive system of male rats. Toxicological \& Environmental Chemistry, 92, 1135-1147. doi:10.1080/02772240903233637

[29] Tkalec, M., Malarić, K., Pavlica, M., Pevalek-Kozlina, B. and Vidakovic-Cifreka, Z. (2009) Effects of radiofrequency electromagnetic fields on seed germination and root meristematic cells of Allium cepa L.. Mutation Research, 672, 76-81. doi:10.1016/j.mrgentox.2008.09.022

[30] Ballardin, M., Tusa, I., Fontana, N., Monorchio, A., Pelletti, C., Rogovich, A., Barale, R. and Scarpatoa, R. (2011) Non-thermal effects of $2.45 \mathrm{GHz}$ microwaves on spindle assembly, mitotic cells and viability of Chinese hamster V-79 cells. Mutation Research, 716, 1-9. doi:10.1016/j.mrfmmm.2011.07.009

[31] Ortner, M.J., Galvin, M.J. and Irwin, R.D. (1983) The effect of $2450 \mathrm{MHz}$ microwave radiation during microtubular polymerization in vitro. Radiation Research, 93, 353-363. doi: $10.2307 / 3575991$

[32] Schrader, T., Munter, K., Kleine-Ostmann, T. and Schmid, E. (2008) Spindle disturbances in human-hamster hybrid (AL) cells induced by mobile communication frequency range signals. Bioelectromagnetics, 29, 626-639. doi: $10.1002 / \mathrm{bem} .20428$

[33] Vander Vorst, A., Rosen, A. and Kotsuka, Y. (2006) $R F /$ Microwave interaction with biological tissues IEEE press, John Wiley \& Sons, Inc, Hoboken.

[34] Blank, M. and Soo, L. (2001) Electromagnetic acceleration of electron transfer reactions. Journal of Cellular Biochemistry, 81, 278-283. doi:10.1002/1097-4644(20010501)81:2<278::AID-JCB1 042>3.0.CO;2-F

[35] Blank, M. (2008) Protein and DNA reactions stimulated by electromagnetic fields. Electromagnetic Biology and Medicine, 27, 3-23. doi:10.1080/15368370701878820

[36] Levin, M. (2003) Bioelectromagnetics in morphogenesis. Bioelectromagnetics, 24, 295-315. doi:10.1002/bem.10104

[37] Lacy-Hulbert, A., Metcalfe, J.C. and Hesketh, R. (1998) Bio-logical responses to electromagnetic fields. The FASEB Journal, 12, 395-420.

[38] Challis, L. (2005) Mechanisms for interaction between RF fields and biological tissue. Bioelectromagnetics, 7, S98-S106. doi:10.1002/bem.20119

[39] Panagopoulos, D.J., Messini, N., Karabarbounis, A., Philippetis, A.L. and Margaritis, L.H. (2000) A Mechanism for Action of Oscillating Electric Fields on Cells Biochemical and Biophysical Research Communications, 272, 634-640. doi:10.1006/bbrc.2000.2746

[40] Irigaray, P. and Belpomme, D. (2010) Basic properties and molecular mechanisms of exogenous chemical carcinogens. Carcinogenesis, 31, 135-148. doi:10.1093/carcin/bgp252

[41] Storz, P. (2005) Reactive oxygen species in tumor progression. Frontiers in Bioscience, 10, 1881-1896. doi: $10.2741 / 1667$

[42] Schmidt, K.N., Amstad, P., Cerutti, P. and Baeuerle, P.A. (1995) The roles of hydrogen peroxide and superoxide as messengers in the activation of transcription factor NFkappa B. Chemistry \& Biology, 2, 13-22. doi:10.1016/1074-5521(95)90076-4

[43] Guijarro, M.V., Leal, J.F.M., Blanco-Aparicio, C., Alonso, S., Fominaya, J., Lleonart, M., Castellvi, J., Ramon y Cajal, S. and Carnero, A. (2007) MAP17 enhances the malignant behavior of tumor cells through ROS increase. Carcinogenesis, 28, 2096-2104. doi:10.1093/carcin/bgm124

[44] WiIttgen, H.G. and Van Kempen, L.C. (2007) Reactive oxygen species in melanoma and its therapeutic implications. Melanoma Research, 17, 400-409. doi:10.1097/CMR.0b013e3282f1d312

[45] Valko, M., Rhodes, C.J., Moncol, J., Izakovic, M. and Mazur, M. (2006) Free radicals, metals and antioxidants in oxidative stress-induced cancer. Chemico-Biological Interactions, 160, 1-40. doi:10.1016/i.cbi.2005.12.009

[46] Giannoni, E., Fiaschi, T., Ramponi, G. and Chiarugi, P. (2009) Redox regulation of anoikis resistance of metastatic prostate cancer cells: Key role for Src and EGFRmediated pro-survival signals. Oncogene, 28, 2074-2086. 
doi:10.1038/onc. 2009.77

[47] Thornber, K., Colomba, A., Ceccato, L., Delsol, G., Payrastre, B. and Gaits-Iacovoni, F. (2009) Reactive oxygen species and lipoxygenases regulate the oncogenicity of NPM-ALK-positive anaplastic large lymphomas. Oncogene, 28, 2690-2696. doi:10.1038/onc.2009.125

[48] Finkel, T. (1998) Oxygen radicals and signaling. Current Opinion in Cell Biology, 10, 248-253. doi:10.1016/S0955-0674(98)80147-6

[49] Bae, G.U., Kim, Y.K., Kwon, H.K., Park, J.W., Lee, E.K., Paek, S.J., Choi, W.S., Jung, I.D., Lee, H.Y., Cho, E.J., Lee, H.W. and Han, J.W. (2004) Hydrogen peroxide mediates Rac1 activation of S6K1. Experimental Cell Research, 300, 476-484. doi:10.1016/j.yexcr.2004.07.013

[50] Abe, J., Okuda, M., Huang, Q., Yoshizumi, M. and Berk, B.C. (2000) Reactive oxygen species activate p90 ribosomal S6 kinase via Fyn and Ras. The Journal of Biological Chemistry, 275, 1739-1748. doi:10.1074/jbc.275.3.1739

[51] Liu, J., Qu, W. and Kadiiska, M.B. (2009) Role of oxidative stress in cadmium toxicity and carcinogenesis. Toxicology and Applied Pharmacology, 238, 209-214. doi:10.1016/j.taap.2009.01.029

[52] Zhou, B.B., Zhang, H., Damelin, M., Geles, K.G., Grindley, J.C. and Dirks, P.B. (2009) Tumour-initiating cells: Challenges and opportunities for anticancer drug discovery. Nature Reviews, 8, 806-823. doi:10.1038/nrd2137

[53] Yeh, C.C., Hou, M.F., Tsai, S.M., Lin, S.K., Hsiao, J.K., Huang, J.C., Wang, L.H., Zsebik, S.B., Citri, A., Isola, J., Yarden, Y., Szollosi, J. and Vereb, G. (2006) Hsp90 inhibitor 17-AAG reduces ErbB2 levels and inhibits proliferation of the trastuzumab resistant breast tumor cell line JIMT-1. Immunology Letters, 104, 146-155. doi:10.1016/j.imlet.2005.11.018

[54] Hortobagyi, G.N.S.S. and Strom, E.A. (2000) Treatment of locally advanced and inflammatory breast cancer. In: Harris, J.R.M.M. and Osbourne, C.K., Eds., Diseases of the breast, Lippincott Williams \& Wilkins, Philadelphia, 645-660.

[55] Moasser, M.M. (2007) The oncogene HER2: Its signaling and transforming functions and its human role in pathogenesis. Oncogene, 26, 6469-6487. doi:10.1038/sj.onc. 1210477

[56] Parton, M., Dowsett, M., Ashley, S., Hills, M., Lowe, F. and Smith, I.E. (2004) High incidence of HER-2 positivity in inflammatory breast cancer. The Breast, 13, 97-103. doi:10.1016/j.breast.2003.08.004

[57] Weisbrot, D., Lin, H., Ye, L., Blank, M. and Goodman, R. (2003) Effects of mobile phone radiation on reproduction and development in Drosophila melanogaster. Journal of Cellular Biochemistry, 89, 48-55. doi:10.1002/jcb.10480

[58] Friedman, J., Kraus, S., Hauptman, Y., Schiff, Y. and Seger, R. (2007) Mechanism of short-term ERK activetion by electromagnetic fields at mobile phone frequentcies. Biochemical Journal, 405, 559-568. doi:10.1042/BJ20061653

[59] Yoon, S. and Seger, R. (2006) The extracellular signalregulated kinase: Multiple substrates regulate diverse cellular functions. Growth Factors, 24, 21-44. doi: $10.1080 / 02699050500284218$

[60] Leszczynski, D., Nylund, R., Joevaara, S. and Reivinen, J. (2004) Applicability of discovery science approach to determine biological effects of mobile phone radiation. Proteonomics, 4, 426-431. doi:10.1002/pmic.200300646

[61] Rao, S. and Henderson, A.S. (1996) Regulation of c-fos is affected by electromagnetic fields. Journal of Cellular Biochemistry, 63, 358-365. doi:10.1002/(SICI)1097-4644(19961201)63:3<358::AIDJCB11>3.0.CO;2-D

[62] Blank, M. and Goodman, R. (2009) Electromagnetic fields stress living cells. Pathophysiology, 16, 71-78. doi:10.1016/j.pathophys.2009.01.006

[63] Chen, F., Castranova, V. and Shi, X. (2001) New insights into the role of nuclear factor-kappa B in cell growth regulation. American Journal of Pathology, 159, 387-397. doi:10.1016/S0002-9440(10)61708-7

[64] Bahassi el, M., Karyala, S., Tomlinson, C.R., Sartorm, M.A., Medvedovic, M. and Hennigan, R.F. (2004) Critical regulation of genes for tumor cell migration by AP-1. Clinical and Experimental Metastasis, 21, 293-304. doi:10.1023/B:CLIN.0000046132.46946.dd

[65] Meylan, E., Dooley, A.L., Feldser, D.M., Shen, L., Turk, E., Ouyang, C. and Jacks, T. (2009) Requirement for NF- $\kappa \mathrm{B}$ signalling in a mouse model of lung adenocarcinoma. Nature, 462, 104-107. doi:10.1038/nature08462

[66] Nakshatri, H., Bhat-Nakshatri, P., Martin, D.A., Goulet Jr, R.J. and Sledge Jr, G.W. (1997) Constitutive activation of NF-kappaB diring progression of breast cancer to hormone-independent growth. Molecular and Cellular Biology, 17, 3629-3639.

[67] Sliva, D., Rizzo, M.T. and English, D. (2002) Phosphatidylinositol 3-kinase and NF-kappaB regulate motility of invasive MDA-MB-231 human breast cancer cells by secretion of urokinase-type plasminogen activator. The Journal of Biological Chemistry, 277, 3150-3157. doi:10.1074/jbc.M109579200

[68] Knight, J.A. (2000) Free radicals, antoxidants, and the immune system. Annals of Clinical \& Laboratory Science, 30, 145-158.

[69] Greten, T.F., Korangy, F., Manns, M.P. and Malek, N.P. (2009) Molecular therapy for the treatment of hepatocellular carcinoma. British Journal of Cancer, 100, 19-23. doi:10.1038/sj.bjc. 6604784

[70] Ma, X., Becker Buscaglia, L.E., Barker, J.R. and Li,Y. (2011) MicroRNAs in NF-kB signaling. Journal of Molecular Cell Biology, 3, 159-166. doi:10.1093/jmcb/mjr007

[71] Cogswell, P.C., Guttridge, D.C., Funkhouser, W.K. and Baldwin Jr, A.S. (2000) Selective activation of NF kappa $\mathrm{B}$ subunits in human breast cancer: Potential roles for NF-kappa B2/p52 and for Bcl-3. Oncogene, 19, 11231131. doi:10.1038/sj.onc. 1203412

[72] Cao, Y. and Karin, M. (2003) NF-kappaB in mammary gland development and breast cancer. Journal of Mammary Gland Biology and Neoplasia, 8, 215-223. doi:10.1023/A:1025905008934 
[73] Biswas, D.K., Shi, Q., Baily, S., Strickland, I., Ghosh, S., Pardee, A.B. and Iglehard, J.D. (2004) NF-kappa B activation in human breast cancer specimens and its role in cell proliferation and apoptosis. Proceedings of the $\mathrm{Na}$ tional Academy of Sciences of the United States of America, 101, 10137-10142. doi:10.1073/pnas.0403621101

[74] Huber, M.A., Azoitei, N., Baumann, B., Grunert, S., Sommer, A., Pehamberger, H., Kraut, N., Beug, H. and Wirth, T. (2004) NF-kappaB is essential for epithelialmesenchymal transition and metastasis in a model of breast cancer progression. Journal of Clinical Investigation, 114, 569-581.

[75] Pikarsky, E., Porat, R.M., Stein, I., Abramovitch, R., Amit, S., Kasem, S., Gutkovich-Pyest, E., Urieli-Shoval, S., Galun, E. and Ben-Neriah, Y. (2004) NF-kappaB functions as a tumour promoter in inflammation-associated cancer. Nature, 431, 461-466. doi: $10.1038 /$ nature 02924

[76] Lerebours, F., Vacher, S., Andrieu, C., Espie, M., Marty, M., Lidereau, R. and Bieche, I. (2008) NF-kappa B genes have a major role in Inflammatory Breast Cancer. $B M C$ Cancer, 8, 41. doi:10.1186/1471-2407-8-41

[77] Bertucci, F., Finetti, P., Rougemont, J., Charafe-Jauffret, E., Nasser, V., Loriod, B., Camerlo, J., Tagett, R., Tarpin, C., Houvenaeghel, G., Jacquemier, J., Houlgatte, R., Birnbaum, D. and Viens, P. (2004) Gene expression profiling for molecular characterization of inflammatory breast cancer and prediction of response to chemotherapy. Cancer Research, 64, 8558-8565. doi:10.1158/0008-5472.CAN-04-2696

[78] Van Laere, S., Van der Auwera, I., Van den Eynden, G.G., Fox, S.B., Bianchi, F., Harris, A.L., van Dam, P., Van Marck, E.A., Vermeulen, P.B. and Dirix, L.Y. (2005) Distinct molecular signature of inflammatory breast cancer by cDNA microarray analysis. Breast Cancer Research and Treatment, 93, 237-246. doi:10.1007/s10549-005-5157-Z

[79] Baldwin Jr, A.S. (1996) The NF-kappaB and IkappaB proteins: new discoveries and insights. Annual Review of Immunology, 14, 649-683. doi:10.1146/annurev.immunol.14.1.649

[80] Chaturvedi, M.M., Sung, B., Yadav, V.R., Kannappan R. and Aggarwal B.B. (2011) NF-kB addiction and its role in cancer: 'One size does not fit all'. Oncogene, 30, 16151630. doi:10.1038/onc. 2010.566

[81] Irmak, M.K., Fadillioglu, E., Gulec, M., Erdogan, H., Yagmurca, M. and Akyol, O. (2002) Effects of electro- magnetic radiation from a cellular telephone on the oxidant and antioxidant levels in rabbits. Cell Biochemistry and Function, 20, 279-283. doi:10.1002/cbf.976

[82] Zmyslony, M., Politanski, P., Rajkowska, E., Szymczak, W. and Jajte, J. (2004) Acute exposure to $930 \mathrm{MHz} \mathrm{CW}$ electromagnetic radiation in vitro affects reactive oxygen species level in rat lymphocytes treated by iron ions. Bioelectromagnetics, 25, 324-328. doi:10.1002/bem.10191

[83] Markovà, E., Malmgren, L.O.G. and Belyaev, I.Y. (2010) Microwaves from mobile phones inhibit 53bp1 focus formation in human stem cells more strongly than in differentiated cells: Possible mechanistic link to cancer risk. Environmental Health Perspectives, 118, 394-399.

[84] Karaca, E., Durmaz, B., Aktug, H., Yildiz, T., Guducu, C., Irgi, M., Koksal, M.G.C., Ozkinay, F., Gunduz, C. and Cogulu, O. (2012) The genotoxic effect of radiofrequency waves on mouse brain. Journal of Neuro-Oncology, 106, 53-58. doi:10.1007/s11060-011-0644-Z

[85] Mantovani, A. (2010) Molecular pathways linking inflammation and cancer. Current Molecular Medicine, 10, 369-373. doi:10.2174/156652410791316968

[86] Pollard, J.W. (2004) Tumour-educated macrophages promote tumour progression and metastasis. Nature Reviews Cancer, 4, 71-78. doi:10.1038/nrc1256

[87] Lewis, C.E. and Pollard, J.W. (2006) Distinct role of macrophages in different tumor microenvironments. Cancer Research, 66, 605-612. doi:10.1158/0008-5472.CAN-05-4005

[88] Coffelt, S.B., Hughes, R. and Lewis, C.E. (2009) Tumorassociated macrophages: Effectors of angiogenesis and tumor progression. Biochimica et Biophysica Acta, 1796, 11-18.

[89] Connelly, L., Barham, W., Onishko, H.M., Chen, L., Sherrill, T.P., Zabuawala, T., Ostrowski, M.C., Blackwell, T.S. and Yull, F.E. (2011) NF-kappaB activation within macrophages leads to an anti-tumor phenotype in a mammary tumor lung metastasis model. Breast Cancer Research, 13, R83. doi:10.1186/bcr2935

[90] Panagopoulos, D.J. and Margaritis, L.H. (2010) The effect of exposure duration on the biological activity of mobile telephony radiation. Mutation Research, 699, 1722. doi:10.1016/j.mrgentox.2010.04.010

[91] Lobry, C. and Weil, R. (2007) New Bcl10 regulation mechanisms: A step in the comprehension of which has occurred in MALT lymphomas? M/S, 23, 353-355. 